\title{
Volumetric, ultrasonic and viscometric studies on L- lysine mono-hydrochloride in aqueous medium at different temperatures
}

\author{
K.C.Patil ${ }^{1}$, Arti Gowardipe ${ }^{2}$ \\ Department of Physics, Janata Mahavidyalaya Chandrapur-442401 (MS), India \\ kc.physics.chd@gmail.com
}

\begin{abstract}
At concentration range (0.001 to 0.06$) \mathrm{mol} / \mathrm{kg}$ and temperature range $\mathrm{T}=(298.15,303.15$ and 308.15) K the densities $(\rho)$, ultrasonic speeds $(u)$ and viscosities $(\eta)$ of aqueous solutions L-Lysine monohydrochloride were measured. From these experimentally measured values, the thermo-dynamical parameters such as apparent molar volume $\left(\phi_{\mathrm{v}}\right)$, apparent molar compressibility $\left(\mathrm{K}_{\mathrm{s} \varphi}\right)$, isentropic compressibility $\left(\mathrm{K}_{\mathrm{s}}\right)$, acoustic impedance $(\mathrm{Z})$, relaxation time $(\tau)$ and classical absorption $\left(\alpha / \mathrm{f}^{2}\right)_{\mathrm{cl}}$ have been evaluated. The results have been interpreted in terms of solute-solvent and solute-solute interactions in this system. It has been observed that there exist strong solute-solvent interactions in these systems and these interactions increases with concentration of solute in aqueous medium.
\end{abstract}

Keywords: Ultrasonic speed, l-lysine mono-hydrochloride, acoustic impedance, apparent molar volume, molecular interactions

\section{INTRODUCTION}

Nowadays, volumetric and ultrasonic characterization of biologically active materials in aqueous medium provides significant information about solute-solvent and solute-solute interactions that help us to understand several biochemical processes such as hydration, aggregation etc. The solute-solvent solutions have large effects on the structure and the properties of biologically important compounds like proteins, carbohydrates etc. L-lysine Mono-hydrochloride is an important $\alpha$-amino acid which is used in biosynthesis of proteins. Lysine is often found buried with only the amino group exposed to solvent [1]. It is essential in human body and it must be obtained from the diet. It appears to help the body to absorb calcium and it plays an important role in the formation of collagen, a substance important for bones and connective tissues including skin, tendons and cartilage [2]. In many biological processes, lysine is an essential amino acid by including retention of endoplasmic reticulum, receptor, affinity, nuclear structure and function, protease cleavage points, chelation of heavy metals and muscles elasticity. It is an important for proper growth and it plays an essential role in the production of carnitine, a nutrient responsible for converting fatty acids into energy and helping to lower cholesterol [3, 4]. From the literature survey it has been observed that scanty work has been done on the study of molecular interactions such as solute-solvent, solute-solute etc. of L-lysine in aqueous medium. Therefore, in the present investigation, we have carried out the volumetric and acoustic characterization of L-lysine in aqueous medium at different concentration and temperature.

\section{EXPERIMENTAL}

L-Lysine mono-hydrochloride an amino acid, CAS No. 657-27-2, AR grade, $99 \%$ pure having molecular weight 182.65 was obtained from Sigma Aldrich chemicals Ltd. The appearance of this chemical is almost white powder. The aqueous solutions of L-lysine mono-hydrochloride of different concentrations was freshly prepared by using double distilled water. The required amount of solute was measured by using a digital weighing machine. The solutions were made on the basis of molality and stored in special airtight bottles to avoid contamination and evaporation. The densities measurements were done by using specific gravity bottle $(10 \mathrm{ml})$. Ultrasonic velocity was determined by using digital ultrasonic pulse echo velocity meter (VCT -70A). The viscosities of the solutions were measured by using Ostwald's type viscometer. The instruments were calibrated with double distilled water at certain temperature before taking measurements. The flow time has been measured with a digital stopwatch and average flow times were taken for each series of liquid solutions.

\section{MATHEMATICAL FORMULATION}

Apparent molal volume measurements $\left(\phi_{v}\right)$

$\phi_{v}=\frac{1000\left(\rho_{0-\rho}\right)}{m \rho \rho_{0}}+\frac{M}{\rho}$

Where, $\rho, \rho_{\mathrm{o}}$ are density of solution and solvent respectively and ' $\mathrm{m}$ ' is concentration of solution. Apparent molar compressibility $\left(\mathrm{k}_{\mathrm{s}} \varphi\right)$

$\mathrm{K}_{\mathrm{s}}, \varphi=\frac{1000\left(K_{S} \rho_{0}-K_{S}^{0} \rho\right)}{m \rho \rho_{0}}+\frac{K_{S} M}{\rho}$

Where, $\mathrm{k}_{\mathrm{s}}$ and $\mathrm{k}_{\mathrm{s}}{ }^{0}$ are the isentropic compressibility of the solution and solvent respectively. 


\section{Available online at www.ijrat.org}

Isentropic Compressibility

$$
\mathrm{K}_{\mathrm{s}}=\frac{1}{u^{2}} \rho
$$

Acoustic Impedance $(\mathrm{Z})$

The specific acoustic impedance is given by

$\mathrm{Z}=\mathrm{U} \rho_{s} \quad \mathrm{Kg} \mathrm{m}^{-2} s^{-1}$

Relaxation Time $(\tau)$

$$
\tau=\frac{4}{3 \beta \eta}
$$

Classical absorption $\left(\alpha / \mathbf{f}^{2}\right)_{\mathrm{cl}}$

$\left(\alpha / \mathfrak{f}^{2}\right)_{\mathrm{cl}}=\frac{8 \pi^{2} \eta}{3 \rho U^{3}}$

Table 1: Experimental data of density, viscosity and ultrasonic velocity of aqueous L-lysine mono-

\begin{tabular}{|c|c|c|c|c|}
\hline $\mathbf{T}(\mathbf{K})$ & c $\left(\right.$ mol.kg $\left.{ }^{-1}\right)$ & $\rho\left(k g \cdot m^{-3}\right)$ & $\eta\left(\mathrm{m}^{-1} \cdot \mathrm{kg} \mathrm{s}^{-1}\right)$ & $\mathbf{u}\left(\mathrm{m} \cdot \mathrm{s}^{-1}\right)$ \\
\hline \multirow[t]{15}{*}{298.15} & 0.001 & 997.130 & 9.179E-04 & 1491.752 \\
\hline & 0.002 & 998.116 & $9.208 \mathrm{E}-04$ & 1492.348 \\
\hline & 0.003 & 998.116 & $9.210 \mathrm{E}-04$ & 1491.752 \\
\hline & 0.004 & 999.103 & $9.220 \mathrm{E}-04$ & 1491.752 \\
\hline & 0.005 & 1000.089 & $9.251 \mathrm{E}-04$ & 1491.752 \\
\hline & 0.006 & 1001.075 & 9.282E-04 & 1491.752 \\
\hline & 0.007 & 1002.061 & $9.312 \mathrm{E}-04$ & 1492.943 \\
\hline & 0.008 & 1003.048 & 9.353E-04 & 1492.943 \\
\hline & 0.009 & 1005.020 & $9.416 \mathrm{E}-04$ & 1492.943 \\
\hline & 0.010 & 1005.020 & $9.421 \mathrm{E}-04$ & 1493.54 \\
\hline & 0.020 & 1006.007 & $9.494 \mathrm{E}-04$ & 1494.733 \\
\hline & 0.030 & 1006.993 & $9.517 \mathrm{E}-04$ & 1496.528 \\
\hline & 0.040 & 1008.965 & 9.580E-04 & 1497.726 \\
\hline & 0.050 & 1010.938 & $9.643 \mathrm{E}-04$ & 1498.927 \\
\hline & 0.060 & 1014.883 & $9.691 \mathrm{E}-04$ & 1500.732 \\
\hline \multirow[t]{15}{*}{303.15} & 0.001 & 995.710 & $7.585 \mathrm{E}-04$ & 1501.540 \\
\hline & 0.002 & 996.697 & 7.640E-04 & 1502.540 \\
\hline & 0.003 & 997.684 & $7.692 \mathrm{E}-04$ & 1503.144 \\
\hline & 0.004 & 998.670 & $7.766 \mathrm{E}-04$ & 1503.748 \\
\hline & 0.005 & 999.657 & 7.787E-04 & 1503.748 \\
\hline & 0.006 & 1000.644 & $7.865 \mathrm{E}-04$ & 1503.748 \\
\hline & 0.007 & 1001.631 & $7.908 \mathrm{E}-04$ & 1503.352 \\
\hline & 0.008 & 1002.618 & $7.954 \mathrm{E}-04$ & 1503.748 \\
\hline & 0.009 & 1003.605 & $7.978 \mathrm{E}-04$ & 1502.54 \\
\hline & 0.010 & 1004.591 & 8.046E-04 & 1503.748 \\
\hline & 0.020 & 1005.578 & 8.096E-04 & 1501.937 \\
\hline & 0.030 & 1006.565 & $8.165 \mathrm{E}-04$ & 1506.171 \\
\hline & 0.040 & 1007.552 & 8.221E-04 & 1506.778 \\
\hline & 0.050 & 1009.526 & 8.273E-04 & 1509.210 \\
\hline & 0.060 & 1010.512 & 8.323E-04 & 1509.819 \\
\hline \multirow[t]{15}{*}{308.15} & 0.001 & 996.058 & $6.760 \mathrm{E}-04$ & 1511.039 \\
\hline & 0.002 & 997.047 & $6.805 \mathrm{E}-04$ & 1511.650 \\
\hline & 0.003 & 998.037 & $6.862 \mathrm{E}-04$ & 1511.429 \\
\hline & 0.004 & 999.026 & $6.888 \mathrm{E}-04$ & 1511.650 \\
\hline & 0.005 & 1000.015 & $6.907 \mathrm{E}-04$ & 1511.650 \\
\hline & 0.006 & 1001.004 & $6.936 \mathrm{E}-04$ & 1511.650 \\
\hline & 0.007 & 1001.993 & $6.981 \mathrm{E}-04$ & 1511.650 \\
\hline & 0.008 & 1002.982 & 7.042E-04 & 1512.872 \\
\hline & 0.009 & 1003.971 & 7.068E-04 & 1512.872 \\
\hline & 0.010 & 1003.971 & $7.110 \mathrm{E}-04$ & 1512.872 \\
\hline & 0.020 & 1004.960 & $7.152 \mathrm{E}-04$ & 1514.711 \\
\hline & 0.030 & 1005.950 & 7.267E-04 & 1515.939 \\
\hline & 0.040 & 1006.939 & $7.281 \mathrm{E}-04$ & 1517.169 \\
\hline & 0.050 & 1007.928 & $7.345 \mathrm{E}-04$ & 1519.017 \\
\hline & 0.060 & 1008.917 & $7.445 \mathrm{E}-04$ & 1519.634 \\
\hline
\end{tabular}
hydrochloride at $298.15 \mathrm{~K}, 303.15 \mathrm{~K}$ and $308.15 \mathrm{~K}$.
4. RESULT AND DISCUSSION
The experimentally measured and evaluated values of physical parameters of aqueous solution of Llysine mono-hydrochloride of different concentrations at $298.15 \mathrm{~K}, 303.15 \mathrm{~K}$ and $308.15 \mathrm{~K}$ are presented in Table-1, Table 2 respectively and their variation with concentration $(0.001-0.06)$ mol. $\mathrm{kg}^{-1}$ at different temperature $(298.15,303.15$ and 308.15) $\mathrm{K}$ are shown in figure 1-9. 
International Journal of Research in Advent Technology, Vol.7, No.4, April 2019

E-ISSN: 2321-9637

\section{Available online at www.ijrat.org}

Table 2: Evaluated thermodynamic parameters of aqueous L-lysine monohydrochloride at 298.15 K, $303.15 \mathrm{~K}$ and $308.15 \mathrm{~K}$.

\begin{tabular}{|c|c|c|c|c|c|c|c|}
\hline $\mathbf{T}(\mathbf{K})$ & c $\underset{1}{\left(\mathrm{~mol}_{1} \mathrm{~kg}^{-}\right.}$ & $\mathrm{K}_{\mathrm{s}}\left(\mathrm{Pa}^{-1}\right)$ & $\begin{array}{l}\mathrm{Z}\left(\mathrm{kg} \mathrm{m}^{-2} \cdot \mathrm{s}^{-}\right. \\
\end{array}$ & $\tau(s)$ & $\begin{array}{l}\boldsymbol{\alpha} / \mathbf{f}^{2} \mathrm{cl} \\
\left(\mathbf{m}^{3} \cdot \mathbf{m o l}\right)\end{array}$ & $\begin{array}{l}\emptyset_{v}\left(\mathrm{~m}^{3} \mathrm{~mol}^{-}\right. \\
\left.\mathbf{1}^{-}\right)\end{array}$ & $\begin{array}{l}\emptyset_{\mathrm{ks}_{\mathrm{s}}\left(\mathrm{m}^{3} \mathrm{~mol}^{-}\right.} \\
\left.{ }^{1} . \mathrm{Pa}^{-1}\right)\end{array}$ \\
\hline \multirow[t]{15}{*}{298.15} & 0.001 & $4.507 \mathrm{E}-10$ & 1483056.182 & $\begin{array}{c}5.532 \mathrm{E}- \\
13\end{array}$ & $7.305 \mathrm{E}-15$ & $1.832 \mathrm{E}-04$ & $1.768 \mathrm{E}-08$ \\
\hline & 0.002 & 4.499E-10 & 1486593.087 & $\begin{array}{c}5.534 \mathrm{E}- \\
13\end{array}$ & 7.305E-15 & $-4.953 \mathrm{E}-01$ & $9.281 \mathrm{E}-09$ \\
\hline & 0.003 & $4.502 \mathrm{E}-10$ & 1490413.245 & $\begin{array}{c}5.523 \mathrm{E}- \\
13\end{array}$ & 7.294E-15 & $-3.301 E-01$ & $6.542 \mathrm{E}-09$ \\
\hline & 0.004 & $4.498 \mathrm{E}-10$ & 1487470.672 & $\begin{array}{c}5.540 \mathrm{E}- \\
13\end{array}$ & $7.316 \mathrm{E}-15$ & $-4.948 \mathrm{E}-01$ & 4.589E-09 \\
\hline & 0.005 & $4.493 \mathrm{E}-10$ & 1490413.245 & $\begin{array}{c}5.548 \mathrm{E}- \\
13\end{array}$ & $7.326 \mathrm{E}-15$ & $-5.932 \mathrm{E}-01$ & 3.774E-09 \\
\hline & 0.006 & 4.489E-10 & 1493355.818 & $\begin{array}{c}5.555 \mathrm{E}- \\
13\end{array}$ & $7.336 \mathrm{E}-15$ & $-6.585 \mathrm{E}-01$ & $3.230 \mathrm{E}-09$ \\
\hline & 0.007 & 4.477E-10 & 1498965.482 & $\begin{array}{c}5.548 \mathrm{E}- \\
13\end{array}$ & $7.321 \mathrm{E}-15$ & $-7.049 \mathrm{E}-01$ & 3.007E-09 \\
\hline & 0.008 & $4.473 \mathrm{E}-10$ & 1491603.176 & $\begin{array}{c}5.600 \mathrm{E}- \\
13\end{array}$ & $7.389 \mathrm{E}-15$ & $-7.394 \mathrm{E}-01$ & 2.307E-09 \\
\hline & 0.009 & 4.464E-10 & 1494548.098 & $\begin{array}{c}5.626 \mathrm{E}- \\
13\end{array}$ & $7.424 \mathrm{E}-15$ & $-8.746 \mathrm{E}-01$ & 2.057E-09 \\
\hline & 0.010 & $4.461 \mathrm{E}-10$ & 1495145.74 & $\begin{array}{c}5.625 \mathrm{E}- \\
13\end{array}$ & $7.420 \mathrm{E}-15$ & $-7.872 \mathrm{E}-01$ & $1.896 \mathrm{E}-09$ \\
\hline & 0.020 & 4.449E-10 & 1503711.156 & $\begin{array}{c}5.632 \mathrm{E}- \\
13\end{array}$ & $7.422 \mathrm{E}-15$ & $-4.423 \mathrm{E}-01$ & 1.113E-09 \\
\hline & 0.030 & $4.434 \mathrm{E}-10$ & 1518800.911 & $\begin{array}{c}5.583 \mathrm{E}- \\
13\end{array}$ & $7.349 \mathrm{E}-15$ & $-3.272 \mathrm{E}-01$ & $9.207 \mathrm{E}-10$ \\
\hline & 0.040 & $4.418 \mathrm{E}-10$ & 1511153.669 & $\begin{array}{c}5.644 \mathrm{E}- \\
13\end{array}$ & $7.423 \mathrm{E}-15$ & $-2.939 \mathrm{E}-01$ & $6.419 \mathrm{E}-10$ \\
\hline & 0.050 & 4.403E-10 & 1509408.71 & $\begin{array}{c}5.683 \mathrm{E}- \\
13\end{array}$ & $7.469 \mathrm{E}-15$ & $-2.738 \mathrm{E}-01$ & $5.091 \mathrm{E}-10$ \\
\hline & 0.060 & $4.375 \mathrm{E}-10$ & 1511225.325 & $\begin{array}{c}5.698 \mathrm{E}- \\
13\end{array}$ & $7.479 \mathrm{E}-15$ & $-2.922 \mathrm{E}-01$ & $4.257 \mathrm{E}-10$ \\
\hline \multirow[t]{13}{*}{303.15} & 0.001 & $4.454 \mathrm{E}-10$ & 1503988.969 & $\begin{array}{c}4.478 \mathrm{E}- \\
13\end{array}$ & $5.875 \mathrm{E}-15$ & $1.834 \mathrm{E}-04$ & 2.849E-09 \\
\hline & 0.002 & $4.444 \mathrm{E}-10$ & 1497576.853 & $\begin{array}{c}4.527 \mathrm{E}- \\
13\end{array}$ & $5.935 \mathrm{E}-15$ & $-4.970 \mathrm{E}-01$ & $4.403 \mathrm{E}-10$ \\
\hline & 0.003 & $4.436 \mathrm{E}-10$ & 1496695.512 & $\begin{array}{c}4.559 \mathrm{E}- \\
13\end{array}$ & $5.974 \mathrm{E}-15$ & $-6.621 \mathrm{E}-01$ & $1.455 \mathrm{E}-10$ \\
\hline & 0.004 & $4.428 \mathrm{E}-10$ & 1497296.921 & $\begin{array}{c}4.599 \mathrm{E}- \\
13\end{array}$ & $6.025 \mathrm{E}-15$ & $-7.441 \mathrm{E}-01$ & $1.087 \mathrm{E}-10$ \\
\hline & 0.005 & 4.424E-10 & 1494329.038 & $\begin{array}{c}4.620 \mathrm{E}- \\
13\end{array}$ & $6.053 \mathrm{E}-15$ & $-7.930 \mathrm{E}-01$ & $-1.621 \mathrm{E}-10$ \\
\hline & 0.006 & 4.419E-10 & 1495812.98 & $\begin{array}{c}4.662 \mathrm{E}- \\
13\end{array}$ & $6.107 \mathrm{E}-15$ & $-8.252 \mathrm{E}-01$ & $-1.209 \mathrm{E}-10$ \\
\hline & 0.007 & $4.417 \mathrm{E}-10$ & 1502836.823 & $\begin{array}{c}4.667 \mathrm{E}- \\
13\end{array}$ & $6.115 \mathrm{E}-15$ & -8.479E-01 & $1.266 \mathrm{E}-10$ \\
\hline & 0.008 & $4.411 \mathrm{E}-10$ & 1492845.097 & $\begin{array}{c}4.724 \mathrm{E}- \\
13\end{array}$ & $6.189 \mathrm{E}-15$ & $-8.647 \mathrm{E}-01$ & $-2.910 \mathrm{E}-10$ \\
\hline & 0.009 & 4.414E-10 & 1494611.354 & $\begin{array}{c}4.736 \mathrm{E}- \\
13\end{array}$ & $6.210 \mathrm{E}-15$ & $-8.776 \mathrm{E}-01$ & $-2.795 \mathrm{E}-10$ \\
\hline & 0.010 & $4.402 \mathrm{E}-10$ & 1495812.98 & $\begin{array}{c}4.770 \mathrm{E}- \\
13\end{array}$ & $6.248 \mathrm{E}-15$ & $-8.877 \mathrm{E}-01$ & $-2.153 \mathrm{E}-10$ \\
\hline & 0.020 & $4.408 \mathrm{E}-10$ & 1498457.999 & $\begin{array}{c}4.796 \mathrm{E}- \\
13\end{array}$ & $6.291 \mathrm{E}-15$ & $-4.926 \mathrm{E}-01$ & $-7.645 \mathrm{E}-11$ \\
\hline & 0.030 & 4.379E-10 & 1499709.526 & $\begin{array}{c}4.820 \mathrm{E}- \\
13\end{array}$ & $6.304 \mathrm{E}-15$ & $-3.608 \mathrm{E}-01$ & $1.564 \mathrm{E}-11$ \\
\hline & 0.040 & 4.372E-10 & 1501800.854 & $\begin{array}{c}4.844 \mathrm{E}- \\
13\end{array}$ & $6.333 \mathrm{E}-15$ & $-2.949 \mathrm{E}-01$ & $4.098 \mathrm{E}-11$ \\
\hline
\end{tabular}


Available online at www.ijrat.org

\begin{tabular}{|c|c|c|c|c|c|c|c|}
\hline & 0.050 & $4.349 \mathrm{E}-10$ & 1507203.484 & $\begin{array}{c}4.849 \mathrm{E}- \\
13\end{array}$ & $6.330 \mathrm{E}-15$ & $-2.747 \mathrm{E}-01$ & 7.756E-11 \\
\hline & 0.060 & $4.341 \mathrm{E}-10$ & 1507811.674 & $\begin{array}{c}4.874 \mathrm{E}- \\
13\end{array}$ & $6.360 \mathrm{E}-15$ & $-2.450 \mathrm{E}-01$ & $7.674 \mathrm{E}-11$ \\
\hline \multirow[t]{15}{*}{308.15} & 0.001 & 4.397E-10 & 1503588.27 & $\begin{array}{c}3.967 \mathrm{E}- \\
13\end{array}$ & $5.172 \mathrm{E}-15$ & $-1.998 \mathrm{E}+00$ & $7.141 \mathrm{E}-10$ \\
\hline & 0.002 & $4.389 \mathrm{E}-10$ & 1501177.157 & $\begin{array}{c}3.974 \mathrm{E}- \\
13\end{array}$ & $5.179 \mathrm{E}-15$ & $-1.497 \mathrm{E}+00$ & $1.232 \mathrm{E}-09$ \\
\hline & 0.003 & 4.386E-10 & 1509956.372 & $\begin{array}{c}4.009 \mathrm{E}- \\
13\end{array}$ & $5.225 \mathrm{E}-15$ & $-1.329 \mathrm{E}+00$ & $6.592 \mathrm{E}-10$ \\
\hline & 0.004 & $4.380 \mathrm{E}-10$ & 1511672.381 & $\begin{array}{c}4.019 \mathrm{E}- \\
13\end{array}$ & $5.238 \mathrm{E}-15$ & $-1.245 \mathrm{E}+00$ & $5.462 \mathrm{E}-10$ \\
\hline & 0.005 & 4.376E-10 & 1516158.056 & $\begin{array}{c}4.018 \mathrm{E}- \\
13\end{array}$ & $5.237 \mathrm{E}-15$ & $-1.194 \mathrm{E}+00$ & $6.261 \mathrm{E}-10$ \\
\hline & 0.006 & $4.372 \mathrm{E}-10$ & 1511672.381 & $\begin{array}{c}4.047 \mathrm{E}- \\
13\end{array}$ & $5.275 \mathrm{E}-15$ & $-1.160 \mathrm{E}+00$ & $2.453 \mathrm{E}-10$ \\
\hline & 0.007 & $4.367 \mathrm{E}-10$ & 1514662.831 & $\begin{array}{c}4.066 \mathrm{E}- \\
13\end{array}$ & $5.298 \mathrm{E}-15$ & $-1.135 E+00$ & $2.836 \mathrm{E}-10$ \\
\hline & 0.008 & 4.356E-10 & 1509901.532 & $\begin{array}{c}4.111 \mathrm{E}- \\
13\end{array}$ & 5.353E-15 & $-1.116 \mathrm{E}+00$ & 7.513E-11 \\
\hline & 0.009 & $4.352 \mathrm{E}-10$ & 1511397.966 & $\begin{array}{c}4.122 \mathrm{E}- \\
13\end{array}$ & $5.367 \mathrm{E}-15$ & $-1.101 \mathrm{E}+00$ & 7.589E-11 \\
\hline & 0.010 & $4.352 \mathrm{E}-10$ & 1512894.4 & $\begin{array}{c}4.142 \mathrm{E}- \\
13\end{array}$ & 5.393E-15 & $-9.909 \mathrm{E}-01$ & $1.198 \mathrm{E}-10$ \\
\hline & 0.020 & $4.337 \mathrm{E}-10$ & 1520726.437 & $\begin{array}{c}4.140 \mathrm{E}- \\
13\end{array}$ & $5.384 \mathrm{E}-15$ & $-5.444 \mathrm{E}-01$ & $2.181 \mathrm{E}-10$ \\
\hline & 0.030 & 4.326E-10 & 1518960.38 & $\begin{array}{c}4.208 \mathrm{E}- \\
13\end{array}$ & $5.468 \mathrm{E}-15$ & $-3.955 \mathrm{E}-01$ & $1.525 \mathrm{E}-10$ \\
\hline & 0.040 & $4.314 \mathrm{E}-10$ & 1518692.147 & $\begin{array}{c}4.213 \mathrm{E}- \\
13\end{array}$ & $5.471 \mathrm{E}-15$ & $-3.210 \mathrm{E}-01$ & $1.305 \mathrm{E}-10$ \\
\hline & 0.050 & $4.300 \mathrm{E}-10$ & 1531059.585 & $\begin{array}{c}4.211 \mathrm{E}- \\
13\end{array}$ & $5.461 \mathrm{E}-15$ & $-2.762 \mathrm{E}-01$ & $1.928 \mathrm{E}-10$ \\
\hline & 0.060 & $4.292 \mathrm{E}-10$ & 1525668.988 & $\begin{array}{c}4.282 \mathrm{E}- \\
13\end{array}$ & $5.551 \mathrm{E}-15$ & $-2.464 \mathrm{E}-01$ & $1.443 \mathrm{E}-10$ \\
\hline
\end{tabular}

When the solution is heated, thermal energy of the solution increases due to which intermolecular separation between the molecules increases and this leads to decrease in density [5, 6] of aqueous L-lysine mono-hydrochloride with rise in temperature (fig. 1 ) at a certain concentration. The viscosity variation of the solution with rise in temperature also indicates the molecular dissociation and supports the facts indicated by density variation with temperature [7-9]. The
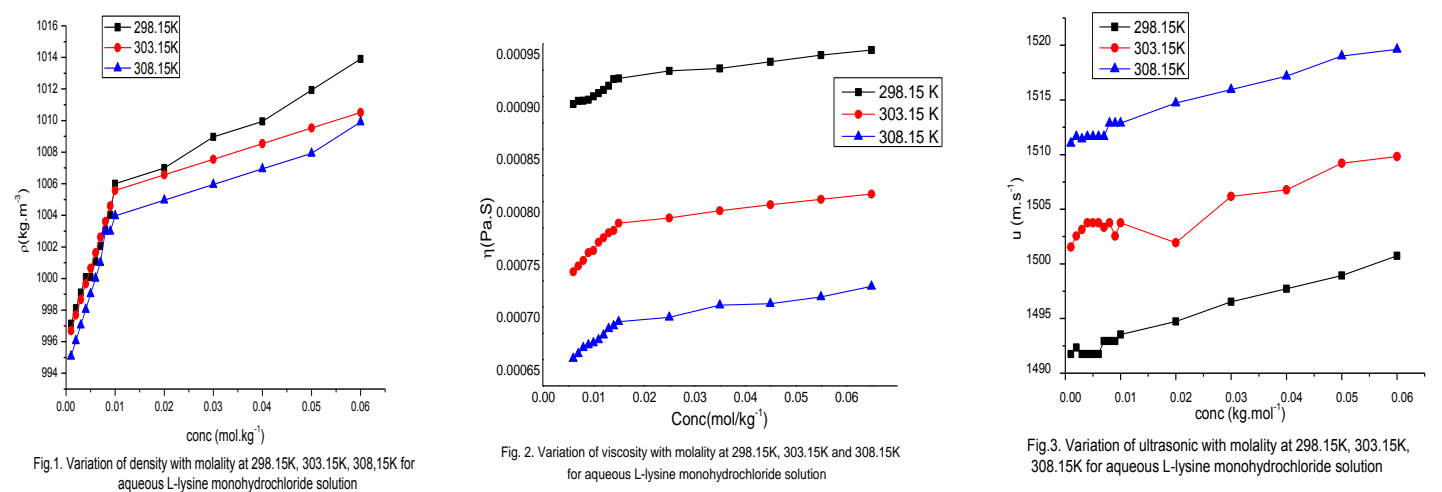

Fig. (1-3): Effect of concentration and Temperature on Density, Viscosity, Ultrasonic Velocity of aqueous Llysine mono-hydrochloride. increase in viscosity (fig.2.) with concentration at a certain temperature indicates molecular association through intermolecular hydrogen bonding. Figure 3 shows that the ultrasonic velocity of solution under the study increases with the increases with concentration as well as temperature. This may be attributed to the increase of compactness of the medium with the increase in solute in water solvent [10-12]. 


\section{Available online at www.ijrat.org}
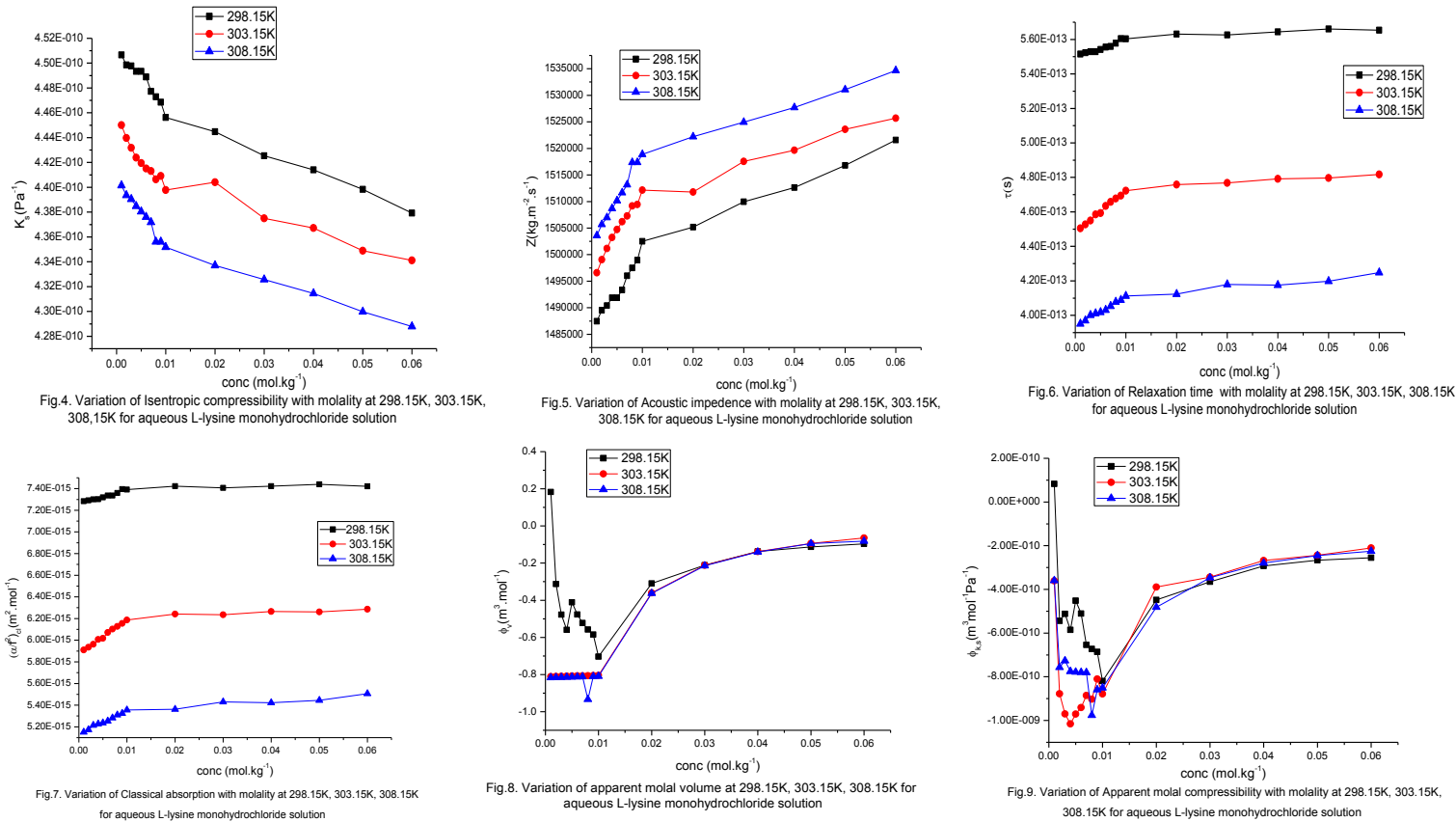

Fig.(4-9) Variation of isentropic compressibility, Acoustic impedence, Relaxation time, Classical absorption, Apparent molal volume and Apparent molal compressibility of aqueous L-lysine mono-hydrochloride at different concentration and temperature.

Figure 4 shows that the isentropic compressibility $\mathrm{K}_{\mathrm{s}, \varphi}$ of aqueous L-lysine mono-hydrochloride decrease with the increase in concentration and temperature. The $\mathrm{K}_{\mathrm{s}, \varphi}$ values are positive and become smaller at higher concentration of aqueous solution and also with increase of temperatures $\mathrm{K}_{\mathrm{s}, \varphi}$ decreases. The similar results are reported by S. J. Kharat [13].

The increase in acoustic impedance with rise in concentration and temperature in the present investigation shows that ultrasound wave has to face resistance to flow. The positive acoustic impedance is an evidential parameter for solutesolvent interaction [14-16]. Decrease in relaxation time (fig.6.) with increase in temperature indicates the weakening of hydrogen bonding in the present system [17]. The increase in relaxation time with concentration at a certain temperature supports the existence of strong interactions between the molecules of the mixtures [18-20].The apparent molal volume, $\varnothing_{\mathrm{v}}$ of L-lysine mono-hydrochloride in water solvent is calculated from the density data. The variation of apparent molal volume with molality of L-lysine monohydrochloride is graphically represented by figure 8 . Figure shows that apparent molal volume is dependent on the concentration as well as on temperature. The values of apparent molal volume of aqueous solution are linearly increase with increase of concentration of amino acids and also increase with decrease in temperature. The apparent molal volume increases with an increase in the number of carbon in alkyl group present in amino acids and it leads to enhanced solute solvent interactions [21]. The apparent molal compressibility $\varnothing_{\mathrm{ks}}$ values of L- lysine mono-hydrochloride in aqueous medium have been reported in table 2 . The negative value of $\emptyset_{\mathrm{ks}}$ (loss of compressibility of medium) indicates enhanced solute solvent interactions. The increase in the values of apparent molal compressibility with concentration indicates strengthening of cohesive forces in the solution [22].

\section{CONCLUSION}

Volumetric and ultrasonic studies of L-lysine in aqueous medium (0.001-0.06) mol kg ${ }^{-1}$ has been carried out with temperature range $(298.15,303.15$ and 308.15) $\mathrm{K}$ with an interval of $5 \mathrm{~K}$. The variation in apparent molal volume and apparent molal compressibility also strongly supports the facts indicated by other basic and derived parameters.

\section{REFERENCES}

[1] Guoyao $\mathrm{Wu}$, Amino Acids biochemistry and Nutrition, CRC Press, 2010, Tayler and Francis group, LLC.

[2] Fini, M, Torricelli, P, Giavaresi, G, Carpi, A, Nicolini, A. and Giardino R., 2001, Effect of L-lysine and L-argineon primary osteoblast cultures from normal and osteopenic rats, Biomed Pharmacother, Vol. 55, pp. 213-220.

[3] Raajvel, E., Humayun, M.A., Ball. O.R. and Paul B., 2007, "Lysine requirement of healthy school-age children determined by the indicator amino acid oxidation method', The American Journal of Chemical nutrition, 86, pp. 360-365. 


\section{Available online at www.ijrat.org}

[4] Meenu Singh, D. Muralidhara Rao, Shivansh Pande, Sowjanya Battu, Mahalakshmi.K, K. Rajeshwar Dutt, M. Ramesh, 2011, Medical Uses of L-lysine Past and Future, International Journal of Research in Pharmaceutical Sciences, Vol. 2(4) pp. 637-642.

[5] Ren, X., Zhu, C. and Ma, Y., 2015, Volumetric and viscometric studies of amino acids in mannitol acqueous solutions at $\mathrm{T}=(293.15 \mathrm{~K}$ to $323.15 \mathrm{~K}) \mathrm{K}$, Journal of Chemical engineering and data, pp. 1787-1802.

[6] K. C. Patil and A. D. Dakhane, 2018, Acoustic and Viscometric Studies on Aqueous N-1Naphthyl Ethylene Diamine Dihydrochloride, Journal of Applicable Chemistry, Vol. 7(5) pp.1436.

[7] Mukhtar Singh and P. Rathore, 2006, Densities, viscosities and excess thermodynamic properties of ternary liquid mixtures of nitrobenzene with polar and nonpolar solvents at $298.15 \mathrm{~K}$, Indian Journal of Chemistry, 45A, pp.2658-2660.

[8] Pal, Amalendu Kumar and Suresh, 2005, Volumetric and viscometric studies of glycine in binary aqueous solutions of sucrose at different temperatures, Indian Journal of Chemistry, 44A (03), pp.469-475.

[9] K. C. Patil and C. M. Dudhe, 2015, Studies on thermodynamic properties of Streptomycin aqueous solutions from $\mathrm{T}=(298.15$ to 308.15 K), Der Pharma Chemica, 7(9), pp. 244.

[10] Islam, Md Monirul., 2014, Studies on volumetric ultrasonic properties of some $\alpha$ amino acids in aqueous solution of monomeric and micellar CTBA at different temperature, Department of chemistry, Rajshahi University, pp. 96-99.

[11] K. C. Patil and Vandana S. Singh 2018, Thermodynamic Properties of Methylamine Hydrochloride in aqueous medium at $298.15 \mathrm{~K}$ and $300.15 \mathrm{~K}$, International Journal of Research in Advent Technology, Vol. 6, No.7 pp. 1453.

[12] K. C. Patil and P. S. Jogi, 2018, Physical Characterization of Triethylamine Hydrochloride Aqueous Solution in Relation to Acoustic and Viscometric Parameters at 298.15 K and 300.15 K, Journal of Applicable Chemistry, Vol. 7(5) pp. 1406.

[13] S.J. Kharat, 2007, density, viscosity and ultrasonic velocity studies of aqueous solutions of sodium acetate at different temperatures, at $\mathrm{T}=(298.15,303.15$ and $313.15 \mathrm{~K})$, Journal of Molecular Liquids, 140, pp. 10-14.

[14] Azam, Md. Golam, 2017, Studies on Volumetric and Sound Velocity of L-proline and L-lysine in Aqueous Nicotinamide Solution at Different Temperature, Kuet institutional repository, pp.161-168

[15] V. A. Giratkar, R. B. Lanjewar, S.M. Gadegone, K. C. Patil, 2017, “Thermoacoustic investigations on L-valinein aqueous salt", Journal of Chemical Biological and Physical Science, 7(3), pp.625.

[16] V. A. Giratkar, R. B. Lanjewar, S.M. Gadegone, K. C. Patil, 2017, Physicochemical investigations on L-Serine in aqueous salt at different Temperature range $\mathrm{T}=(288.15$ to 303.15 K), Journal of Chemical Biological and Physical Science, 7(3), pp.670-671.

[17] Kumar, D. Sravana Rao, D. Krishna, 2007, study of molecular interactions and ultrasonic velocity in mixtures of some alkonols with aqueous propylene, glycol, Indian Journal of Pure and Applied Physics, 45(3), 210-220.

[18] C. Shanmuga Priya et.al, 2010, Molecular interactions studies in liquid mixture using Ultrasonic technique, International Journal of Advanced Science and Technology, 18, pp.5974.

[19] K. C. Patil and C. M. Dudhe, 2016, "Acoustical and Viscometric Studies of Gentamicin Sulphate in aqueous medium", Der Pharma Chemica, 8(20). pp. 232.

[20] K. C. Patil and C. M. Dudhe, 2015, Molecular interaction study of aqueous solution of an aminoglycoside antibiotic Neomycin at 298.15 to $308.15 \mathrm{~K}$, Der Pharma Chemica, 7(12) pp. 225 .

[21] K. Rajagopal, J. Johnson, 2015, Thermodynamic interaction of L-histidine in aqueous fructose solutions at different temperatures, International Journal of Scientific and Research Publications, 5, pp.17.

[22] Anil Kumar Nain, Renu Pal, Neetu, 2013, Volumetric, ultrasonic and viscometric studies of L-threonine in aqueous-sucrose solutions at different temperatures, Journal of Chemical Thermodynamics, 64, pp.72-181. 